\title{
Article \\ Phenolic Compounds Profile and Antioxidant Capacity of Pitahaya Fruit Peel from Two Red-Skinned Species (Hylocereus polyrhizus and Hylocereus undatus)
}

\author{
Wanpei Tang ${ }^{1,+}, \mathrm{Wu} \mathrm{Li}^{1,+}{ }^{1}$, Yuzhe Yang ${ }^{2}$, Xue $\operatorname{Lin}{ }^{1, *} \mathbb{C}$, Lu Wang ${ }^{1}$, Congfa $\mathrm{Li}^{1}$ and Ruili Yang ${ }^{2, *}$ \\ 1 Key Laboratory of Food Nutrition and Functional Food of Hainan Province, College of Food Science and \\ Engineering, Hainan University, Haikou 570228, China; 18083200210009@hainanu.edu.cn (W.T.); \\ leewuu@163.com (W.L.); lwang@hainanu.edu.cn (L.W.); congfa@vip.163.com (C.L.) \\ 2 College of Food Science, South China Agricultural University, Guangzhou 510642, China; yz3794847@163.com \\ * Correspondence: linxiaoxuelx@163.com (X.L.); rlyang77@scau.edu.cn (R.Y.); \\ Tel.: +86-898-6619-8861 (X.L.); +86-20-8528-3448 (R.Y.) \\ + These authors contributed equally to this article.
}

check for updates

Citation: Tang, W.; Li, W.; Yang, Y.; Lin, X.; Wang, L.; Li, C.; Yang, R. Phenolic Compounds Profile and Antioxidant Capacity of Pitahaya Fruit Peel from Two Red-Skinned Species (Hylocereus polyrhizus and Hylocereus undatus). Foods 2021, 10, 1183. https://doi.org/10.3390/ foods10061183

Academic Editor: Irina Ioannou

Received: 27 April 2021

Accepted: 21 May 2021

Published: 25 May 2021

Publisher's Note: MDPI stays neutral with regard to jurisdictional claims in published maps and institutional affiliations.

Copyright: (c) 2021 by the authors. Licensee MDPI, Basel, Switzerland. This article is an open access article distributed under the terms and conditions of the Creative Commons Attribution (CC BY) license (https:// creativecommons.org/licenses/by/ $4.0 /)$

\begin{abstract}
Pitahaya peel is a good source of bioactive polyphenols. However, the bound phenolics and their antioxidant activity remain unclear. The bound phenolics of pitahaya peel from two red-skinned species with red pulp (RP) and white pulp (WP) were released with different methods (acid, base, and composite enzymes hydrolysis). The results revealed that base hydrolysis was the most efficient method for releasing the bound phenolics from RP (11.6 mg GAE/g DW) and WP (10.5 mg GAE/g DW), which was 13.04-fold and 8.18-fold for RP and 75.07-fold and 10.94-fold for WP compared with acid hydrolysis and enzymatic hydrolysis, respectively. A total of 37 phenolic compounds were identified by UPLC-TOF/MS with most chlorogenic acid, caffeic acid, ferulic acid and $p$-coumaric acid in RP, whereas chlorogenic acid, caffeic acid, ferulic acid, rutin and isoquercitrin were the main compounds in WP. Regardless of the hydrolysis method, the extracts having the highest phenolic content showed the strongest antioxidant activities. The work shows that hydrolysis methods have a significant effect on the release of phenolics, and the contents of major characteristic bound phenolic compounds are related to the ecological type of pitahaya.
\end{abstract}

Keywords: bound phenolics; pitahaya peel; antioxidant capacity; hydrolysis

\section{Introduction}

Hylocereus is a native American cactus of varied habits and widely distributed from the Florida coast to Brazil. The fruit is known under several commercial and native names, but "pitahaya" or "pitaya" prevails all around [1]. Among them, red pitahaya (Hylocereus spp.), fruits with a red skin and red (Hylocereus polyrhizus) or white (Hylocereus undatus) pulp are the most common commercial species [2]. In recent years, with the improvement of people's living standards and health consciousness, fruit products for high nutrients have been favored by consumers. Pitahaya has attracted attention because it is a promising source of nutrients of exerting positive effects on the consumers' health. Pitahaya peel, accounting for approximately $33 \%$ of the whole fruit weight, is often discarded and ends up as waste in the process of industrial processing, which causes considerable environmental pollution [3].

It is a truth universally acknowledged that fruit peel is a good source of bioactive compounds, such as phenolics $[4,5]$. Phenolic compounds have attracted much attention because of their potential healthy effects, such as antioxidant, anticancer cell and anti-diabetes activities [6,7]. In general, natural phenolic compounds that exist in plant matrices occur mostly as free and bound forms (covalently bound to sugar moieties or cell wall structural components) [8]. Free phenolics can easily be extracted from various matrices, while bound phenolic compositions which occupy about $35-65 \%$ of the phenolic compounds in plant 
matrices are usually released by acidic hydrolysis, saponification (base/alkaline hydrolysis) and enzymatic reactions [9-12]. Alkaline hydrolysis is the commonly strategy to release the bound phenolics, which entails treating the sample with $\mathrm{NaOH}$ solution (about 1-4 M) for 15 min up to overnight. As for acidic hydrolysis, it was efficient to break glycosidic bond and then to release the bound form phenolics [13]. Currently, composite enzymatic treatment has been in the spotlight to extract bound phenolics for the low cost and environmentally friendly feature. However, due to the differences of plant materials and substrates, there are differences in the ability of these methods to release bound phenolics [14-16].

It has previously been observed that the total free phenol content of red pitahaya peel and white pitahaya peel were $14.82 \mathrm{mg} / \mathrm{g}$ and $15.94 \mathrm{mg}$ GAE (gallic acid equivalent)/g of dried sample [17]. Currently, over 23 polyphenol compounds have been identified from flesh and peel of red pitahaya fruits (gallic acid, protocatechuic acid, vanillic acid, caffeic acid, syringic acid, p-coumaric acid, isorhamnetin triglycoside, quercetin-3-O-rutinoside, flavonol glycoside and so on) by HPLC-DAD and HPLC-MS-MS [3,18]. However, most previous studies on pitahaya peel have focused only on free phenolic compounds [18-20]. To our knowledge, the bound phenolic compounds and their contributions to total phenolic compounds and antioxidant activities remain to be elucidated.

The aim of this study was to compare the efficiency of the acid, base, and composite enzymes hydrolysis in releasing bound phenolic compounds from red-pulp and whitepulp pitahaya peel. The released phenolic compounds resulting from different extraction methods were identified and quantified using ultra performance liquid chromatography (UPLC) and UPLC-Q-Exactive Orbitrap mass spectrometry. Moreover, the antioxidant activity of phenolic fractions was also investigated.

\section{Materials and Methods}

\subsection{Chemicals and Reagents}

Epicatechin, kaempferol, quercetin, rutin, isoquercitrin, syringic acid, $p$-coumaric acid, chlorogenic acid, cryptochlorogenic acid, caffeic acid, ferulic acid and gallic acid were purchased from Adamas Reagent, Ltd. (Shanghai, China). Other standard reference materials including 4-methoxysalicylic acid, $p$-hydroxycinnamic acid, isoferulic acid, 1,3dicaffeoylquinic acid, gentiopicrin, grosvenorine, diosmin, isorhamnetin and baicalein were obtained from Shanghai Yuanye Bio-Technology Co., Ltd. (Shanghai, China). 2,4,6tri(pyridin-2-yl)-1,3,5-triazine (TPTZ), 1,1-diphenyl-2-picrylhydrazyl (DPPH), 2,2' -azinobis (3-ethylbenzothiazoline-6-sulfonic acid (ABTS), 4-nitrophenyl $\alpha$-D-glucopyranoside ( $p$-NPG) were all obtained from Adamas Reagent, Ltd. (Shanghai, China). Acetonitrile and formic acid (99.9\%, HPLC grade) were obtained from Thermo Fisher Scientific (Waltham, MA, USA). Cellulase (400 u/mg) from Trichoderma Vride $G$, hemicellulase $(20,000 \mathrm{u} / \mathrm{g})$ and pectinase $(500 \mathrm{u} / \mathrm{mg}$ ) from Aspergillus niger were all supplied from Shanghai Yuanye Bio-Technology Co., Ltd. (Shanghai, China). All other reagents and chemicals used in this study are analytical grade.

\subsection{Plant Materials Collection and Preparation}

Red-pulp and white-pulp pitahaya fruits at commercial maturity, no mildew and deterioration, were purchased from Haikou Ledong Pitahaya Planting Base (Ledong, China). Red-pulp pitahaya peel (RP) and white-pulp pitahaya peel (WP) were separated and lyophilized and powdered to a fine powder and stored at $-20^{\circ} \mathrm{C}$ until analysis.

\subsection{Different Extraction Methods}

\subsubsection{Free Phenolics by Methanol}

Extraction of free phenolics from the RP and WP was performed according to Li et al. [21] (Figure 1). Briefly, the dried pitahaya peel powder $(0.5 \mathrm{~g})$ were mixed with $15 \mathrm{~mL}$ of $80 \%$ methanol solution (including $1 \%$ formic acid). Ultrasonic cleaner (KQ$500 \mathrm{DE}$, Kun shan, Jiangsu, China) was used to ultrasonic the mixture at $400 \mathrm{~W}$ power and $25^{\circ} \mathrm{C}$ for $30 \mathrm{~min}$. The supernatant was collected after centrifugation at $4000 \mathrm{r} / \mathrm{min}$ for 
$15 \mathrm{~min}$. Residues were re-extracted twice as above. The supernatants were combined and concentrated with a rotary evaporator at $45^{\circ} \mathrm{C}$ avoiding light, and the resulting extracts were dissolved in $70 \%$ methanol (final volume, $10 \mathrm{~mL}$ ) for determination. This was the free phenolics of RP and WP (F1 and F2).

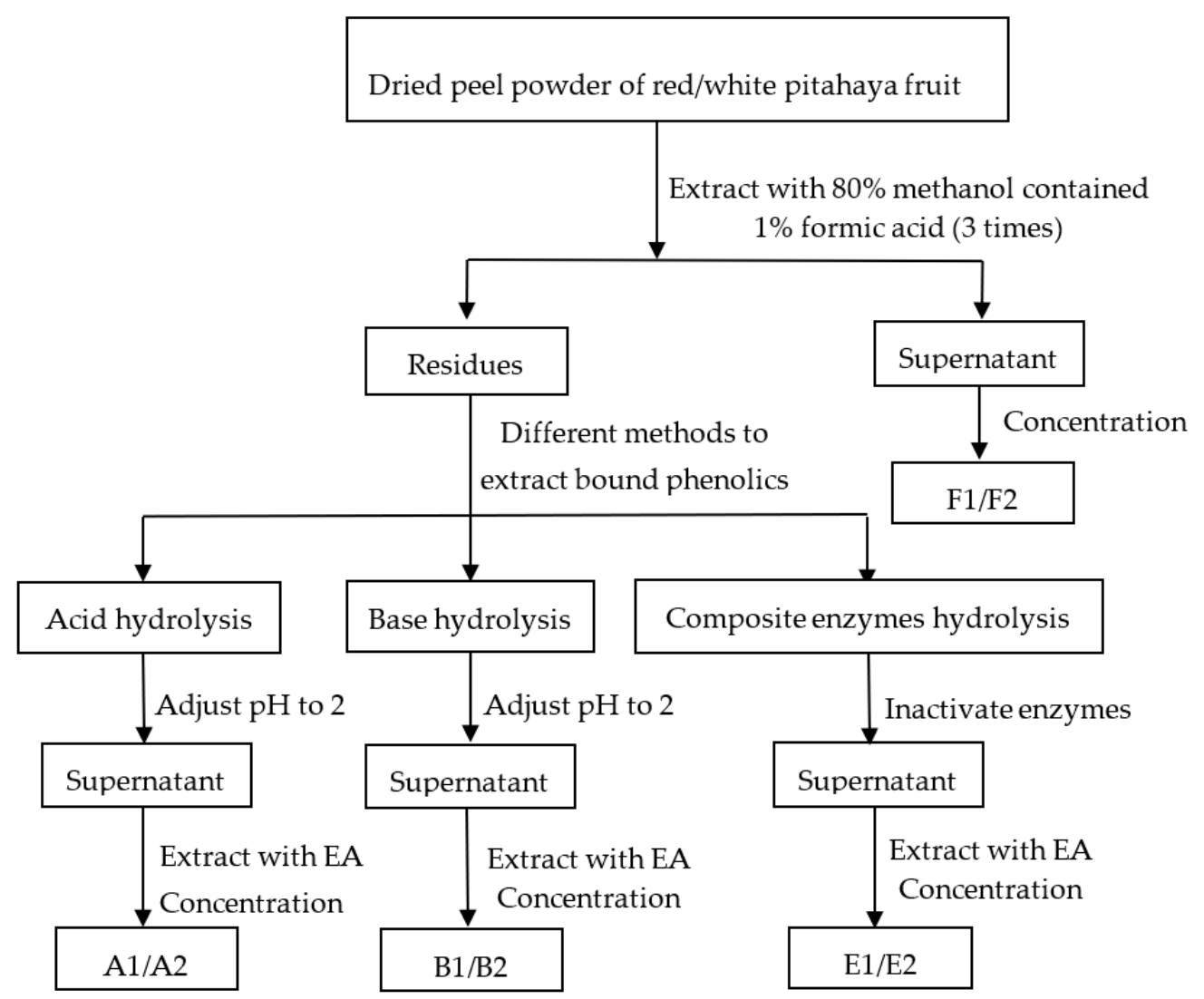

Figure 1. Phenolic fractions extraction procedures. EA, Ethyl acetate; F1, free phenolics of red pitahaya peel by methanol extraction; F2, free phenolics of white pitahaya peel by methanol extraction; A1, bound phenolics of red pitahaya peel by acid hydrolysis; A2, bound phenolics of white pitahaya peel by acid hydrolysis; B1, bound phenolics of red pitahaya peel by base hydrolysis; B2, bound phenolics of white pitahaya peel by base hydrolysis; E1, bound phenolics of red pitahaya peel by composite enzymes hydrolysis; E2, bound phenolics of white pitahaya peel by composite enzymes hydrolysis.

\subsubsection{Bound Phenolics by Acid Hydrolysis}

The dried residue $(0.5 \mathrm{~g})$ generated after free phenolics extraction was hydrolyzed with $15 \mathrm{~mL}$ of $\mathrm{HCl}(3 \mathrm{M})$ filled with nitrogen. The mixture was kept in water bath at $85{ }^{\circ} \mathrm{C}$ for $60 \mathrm{~min}$ and then adjusted the $\mathrm{pH}$ to 2 using $\mathrm{NaOH}$ solution $(10 \mathrm{M})$, centrifuged at $10,000 \times g$ for $5 \mathrm{~min}$. The supernatant was extracted with $20 \mathrm{~mL}$ of ethyl acetate (EA) four times. All of the supernatants were concentrated with a rotary evaporator at $45^{\circ} \mathrm{C}$ avoiding light, and used $70 \%$ methanol to constant volume of $10 \mathrm{~mL}$ for determination. This was the bound phenolics of RP and WP by acid hydrolysis (A1 and A2).

\subsubsection{Bound Phenolics by Base Hydrolysis}

The dried residue $(0.5 \mathrm{~g})$ generated after free phenolics extraction was hydrolyzed with $15 \mathrm{~mL}$ of $\mathrm{NaOH}(3 \mathrm{M})$ solution containing $10 \mathrm{mM}$ EDTA-2 $\mathrm{Na}$ and $1 \%$ ascorbic acid filled with nitrogen gas. The mixture was incubated in a shaking water bath for $4 \mathrm{~h}$ at $30{ }^{\circ} \mathrm{C}$, then adjusted the $\mathrm{pH}$ to 2 using $\mathrm{HCl}(6 \mathrm{M})$, centrifuged at $10,000 \times g$ for $15 \mathrm{~min}$. The supernatant was extracted with $20 \mathrm{~mL}$ of EA four times. All of the supernatants were concentrated with a rotary evaporator at $45^{\circ} \mathrm{C}$ avoiding light, and then added $70 \%$ methanol to constant volume of $10 \mathrm{~mL}$ for determination. This was the bound phenolics of $\mathrm{RP}$ and WP by base hydrolysis (B1 and B2). 


\subsubsection{Bound Phenolics by Composite Enzymes Hydrolysis}

The dried residue $(0.5 \mathrm{~g})$ generated after free phenolics extraction was mixed with $0.03 \mathrm{~g}$ of composite enzymes (cellulase:hemicellulase:pectinase $=1: 1: 1$ ), adding $10 \mathrm{~mL}$ of $\mathrm{H}_{2} \mathrm{O}$ (adjusted to $\mathrm{pH}=5.0$ using citric acid) to the mixture, which was incubated in a $50{ }^{\circ} \mathrm{C}$ shaking water bath for $2 \mathrm{~h}$. After the enzymatic hydrolysis, the mixtures were kept at oven for $10 \mathrm{~min}$ at $80^{\circ} \mathrm{C}$ to inactivate the enzymes, then ultrasonic extracted for $30 \mathrm{~min}$ at $50{ }^{\circ} \mathrm{C}$ with $320 \mathrm{~W}$ of ultrasonic power [13]. Before centrifuged at $12,000 \times \mathrm{g}$ for $10 \mathrm{~min}$, a water/ice bath was used to cool the mixtures to $25^{\circ} \mathrm{C}$. The supernatant was extracted with $20 \mathrm{~mL}$ of EA four times. All of the supernatants were concentrated with a rotary evaporator at $45{ }^{\circ} \mathrm{C}$ avoiding light, and then added $70 \%$ methanol to constant volume of $10 \mathrm{~mL}$ for determination. This was the bound phenolics of RP and WP by composite enzymes hydrolysis (E1 and E2).

\subsection{Analyses of Total Phenolic and Total Flavonoid Contents}

The concentration of total phenolic compounds was determined using Folin-Ciocalteu reagent according to Singh et al. [22] with slight modification. Briefly, $150 \mu \mathrm{L}$ of extracts was added to $3 \mathrm{~mL}$ distilled water, and oxidized with $500 \mu \mathrm{L}$ of Folin-Ciocalteu reagent for $8 \mathrm{~min}$ at room temperature. Then, the reaction was neutralized with $700 \mu \mathrm{L}$ of $15 \%$ sodium carbonate added with mixing. The solution was incubated at $30^{\circ} \mathrm{C}$ for $60 \mathrm{~min}$ before taking the absorbance at $765 \mathrm{~nm}$. All tests were performed in triplicates. Gallic acid $(10-100 \mu \mathrm{g} / \mathrm{mL})$ was used as the standard $\left(R^{2}=0.999\right)$. The results were expressed as $\mathrm{mg}$ GAE (gallic acid equivalents)/g DW (dry weight) of the sample extract.

The concentration of total flavonoids compounds was determined using aluminium chloride procedure referred to Pascoa et al. [23] with slight modification. $500 \mu \mathrm{L}$ of extracts was added to $2 \mathrm{~mL}$ methanol, mixed with $150 \mu \mathrm{L}$ of $5 \% \mathrm{NaNO}_{2}$ solution $(w / v)$. After $6 \mathrm{~min}, 150 \mu \mathrm{L}$ of $10 \% \mathrm{AlCl}_{3}$ solution $(w / v)$ was added. $2 \mathrm{~mL}$ of $\mathrm{NaOH}(1 \mathrm{M})$ was added to terminate the reaction after $6 \mathrm{~min}$. The solution was incubated at room temperature for $20 \mathrm{~min}$ before taking the absorbance at $510 \mathrm{~nm}$. All tests were performed in triplicates. Rutin $(10-100 \mu \mathrm{g} / \mathrm{mL})$ was used as the standard $\left(R^{2}=0.999\right)$. The results were expressed as mg RE (Rutin equivalents)/g DW (dry weight) of the sample extract.

\subsection{UPLC-TOF-MS Analysis}

Q-Exactive Obitrap MS (Thermofisher Scientific, Shanghai, China) coupled to an electrospray ionisation (ESI) source was used to elute phenolic compounds. Separation of polyphenols was carried out on an Agilent ZORBAX Eclipse Plus C18 $(2.1 \times 100 \mathrm{~mm}$, $1.8 \mu \mathrm{m})$. The mobile phases A and B were $0.2 \%$ formic acid in Milli-Q grade water and $100 \%$ acetonitrile, respectively. The gradient was as follows: $0-10 \mathrm{~min} 10-30 \% \mathrm{~B}, 10-15 \mathrm{~min} 30 \%$ to $90 \% \mathrm{~B}, 15-16 \mathrm{~min} 90 \%$ to $10 \% \mathrm{~B}, 16-20 \mathrm{~min} 10 \% \mathrm{~B}$. The flow rate was set at $0.3 \mathrm{~mL} / \mathrm{min}$ and injection volume was $3 \mu \mathrm{L}$. Capillary voltage was maintained at $3200 \mathrm{~V}$. Nitrogen was used as sheath gas flow 30 arb and aux gas flow10 arb. Mass spectra (MS) spectra were recorded in negative ion mode, in the range of $105-1100 \mathrm{~m} / \mathrm{z}$.

Identification of phenolics in the extracts was achieved by comparing their spectra and retention times with those of externally injected standards (Table 1): rutin $>99 \%$; gallic acid, chlorogenic acid, cryptochlorogenic acid, kaempferol, caffeic acid, syringic acid, epicatechin, $p$-coumaric acid, sinapic acid, $p$-hydroxycinnamic acid, nicotiflorin, isoferulic acid, ferulic acid, grosvenorine, isorhamnetin, baicalein $>98 \%$; astragalin, 1,3-dicaffeoylquinic acid, gentiopicrin and diosmin $>97 \%$; isoquercitrin, quercitrin, 4-methoxysalicylic acid $>95 \%$. The precise mass of the parent ion $(\mathrm{M}-\mathrm{H})$ and typical MS fragmentation pattern were used to identify compounds which standards were not available according to references. The concentration of each phenolic compound in the extracts was measured with a standard. For quantification, external calibration curves were prepared for each standard. 
Table 1. Calibration curves used for UPLC-MS/MS quantification of polyphenols.

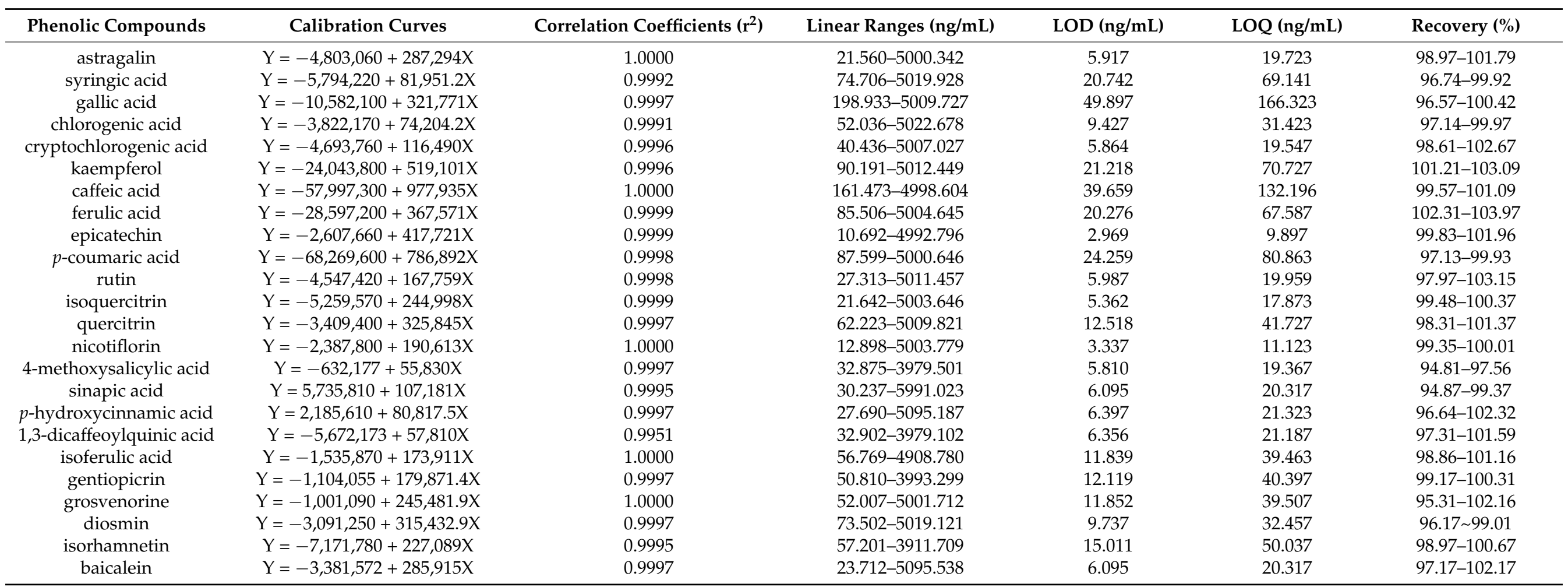




\subsection{Antioxidant Activity}

The DPPH radical scavenging assay followed the method reported by Arnab et al. [24] with slight modification. A $50 \mu \mathrm{L}$ volume of sample was mixed with $400 \mu \mathrm{L}$ DPPH methanolic solution $(100 \mu \mathrm{M})$ and allowed to stand at room temperature for 30 min under light protection. Each solution $(200 \mu \mathrm{L})$ was added into a 96-well plate and absorbances were measured at $517 \mathrm{~nm}$ using a microplate reader. Methanol was used as a blank control. Trolox $(10-150 \mu \mathrm{g} / \mathrm{mL})$ was used as the standard $\left(R^{2}=0.991\right)$. The results were expressed as $\mu \mathrm{mol} \mathrm{TE}$ (Trolox equivalents)/g DW (dry weight) of the sample extract.

The ABTS cation radical scavenging activity followed the method reported by van der Werf et al. [25]. Briefly, $10 \mathrm{~mL}$ ABTS solution $(7.0 \mathrm{mM})$ was mixed with $176 \mu \mathrm{L}$ potassium persulfate solution $(140 \mathrm{mM})$. After incubated at room temperature for $12 \mathrm{~h}$ in darkness, the stock solution was diluted with PBS $\left(0.05 \mathrm{M} \mathrm{K}_{2} \mathrm{HPO}_{4}, 0.05 \mathrm{M} \mathrm{KH}_{2} \mathrm{PO}_{4}, \mathrm{pH}\right.$ 6.8) until the absorbance was $0.7 \pm 0.02$. A $200 \mu \mathrm{L}$ volume of sample was mixed with $4 \mathrm{~mL}$ diluted $\mathrm{ABTS}^{+}$stock solution and allowed to stand at room temperature for 6 min under light protection. Each solution $(200 \mu \mathrm{L})$ was added into a 96 -well plate and absorbances were measured at $734 \mathrm{~nm}$ using a microplate reader. Trolox $(10-100 \mu \mathrm{g} / \mathrm{mL})$ was used as the standard $\left(R^{2}=0.993\right)$. The results were expressed as $\mu \mathrm{mol}$ TE (Trolox equivalents) $/ \mathrm{g} D W$ (dry weight) of the sample extract.

The ferric reducing antioxidant power (FRAP) assay followed method reported by Chen et al. [26]. Briefly, the FRAP reagent was prepared by mixing acetate buffer ( $300 \mathrm{mM}$, $\mathrm{pH}$ 3.6), a solution of $10 \mathrm{mM}$ TPTZ in $40 \mathrm{mM} \mathrm{HCl}$ and $20 \mathrm{mM} \mathrm{FeCl}_{3}$ at 10:1:1 $(v / v / v)$. Reagents were manufactured freshly and warmed to $37^{\circ} \mathrm{C}$ in a water bath. A $30 \mu \mathrm{L}$ volume of sample was mixed with $900 \mu \mathrm{L}$ FRAP solutions and allowed to stand at room temperature for $30 \mathrm{~min}$ under light protection. Each solution $(200 \mu \mathrm{L})$ was added into a 96 -well plate and absorbances were measured at $593 \mathrm{~nm}$ using a microplate reader. $\mathrm{FeSO}_{4} \cdot 7 \mathrm{H}_{2} \mathrm{O}$ $(0-800 \mu \mathrm{mol} / \mathrm{mL})$ was used as the standard $\left(R^{2}=0.999\right)$. The results were expressed as $\mu \mathrm{mol} \mathrm{Fe}(\mathrm{II}) \mathrm{SE}$ (ferrous sulfate equivalents)/g DW (dry weight) of the sample extract.

\subsection{Statistical Analysis}

All experiments were carried out in triplicate and the data were expressed as mean \pm standard deviation. SPSS (version 26.0.) was used to perform statistical analyses. ANOVA test (Tuckey's and Bonferroni) were applied to compare means. Differences were considered significant at the $p<0.05$ level.

\section{Results and Discussion}

\subsection{Free and Bound Polyphenols Extracted by Different Methods}

Phenolic compounds can be divided into free and bound forms, depending on whether they occur in the free form or are covalently bound to other molecules [27]. Free phenolic compounds are easily extracted by organic solvents, while a large amount of bound phenolics are difficult to extract [13]. In the present study, the contents and compositions of free phenolics by conventional methods ( $80 \%$ methanol extraction) and bound phenolics released by various hydrolysis methods (acid, base, and composite enzymes) in RP and WP were analyzed, respectively. As shown in Figure 2a, free phenolic contents of RP and WP was $11.3 \mathrm{mg} \mathrm{GAE} / \mathrm{g}$ DW and $10.1 \mathrm{mg} \mathrm{GAE} / \mathrm{g}$ DW, respectively. The content of free flavonoids in RP $(5.4 \mathrm{mg}$ RE/g DW) was significantly $(p<0.05)$ higher than that in WP (3.3 mg RE/g DW) (Figure 2b). The results indicated that the species of pitahaya fruit had influence on the contents of free phenolics. Free flavonoid contents in pitahaya fruit peel were slight lower than that reported by Kim, Choi, Moon, Kim, Mosaddik and Cho [17]. It may be due to the differences in species and cultivated regions of pitahaya fruit samples.

Bound phenolic content in the basic extracts was $11.6 \mathrm{mg}$ GAE/g DW for RP and $10.5 \mathrm{mg}$ GAE/g DW for WP. The contribution of bound phenolics to total phenolics (free and bound) in RP and WP was $50.72 \%$ and $50.95 \%$, respectively. The data obtained indicated that the polyphenols content of pitahaya fruit peel has been underestimated in the literature. As shown in Figure 2, hydrolysis methods exhibited significant impacts on 
the release efficiency of bound phenolics. The amounts of bound phenolics released by acidic hydrolysis ( $0.9 \mathrm{mg}$ GAE/g DW and $0.1 \mathrm{mg}$ GAE/g DW for RP and WP, respectively) were robustly lower than that of basic hydrolysis. The bound flavonoid amounts released by acidic hydrolysis were $1.6 \mathrm{mg}$ RE/g DW for RP and $0.9 \mathrm{mg}$ RE/g DW for WP. Similarly, the amounts of bound phenolics released by composite enzyme hydrolysis were extremely low (1.4 mg GAE/g DW for RP and $1.0 \mathrm{mg} \mathrm{GAE} / \mathrm{g}$ DW for WP). The bound flavonoid amounts released by composite enzyme hydrolysis were $1.6 \mathrm{mg}$ RE/g DW and $1.2 \mathrm{mg}$ $\mathrm{RE} / \mathrm{g} \mathrm{DW}$, respectively. Importantly, base hydrolysis yielded the highest bound phenolic contents, which was 13.04-fold and 8.18-fold for RP and 75.07-fold and 10.94-fold for WP compared with acid and enzymatic hydrolysis, respectively. It also yielded the highest bound flavonoid contents (2.6 mg RE/g DW for RP and $2.2 \mathrm{mg}$ RE/g DW for WP), which was 1.69-fold and 1.69-fold for RP and 2.57-fold and 1.95-fold for WP compared with acid and enzymatic hydrolysis, respectively. Moreover, the contents of phenolics and flavonoids in RP were higher than those of WP varieties by the correspondingly same hydrolysis methods $(p<0.05)$.

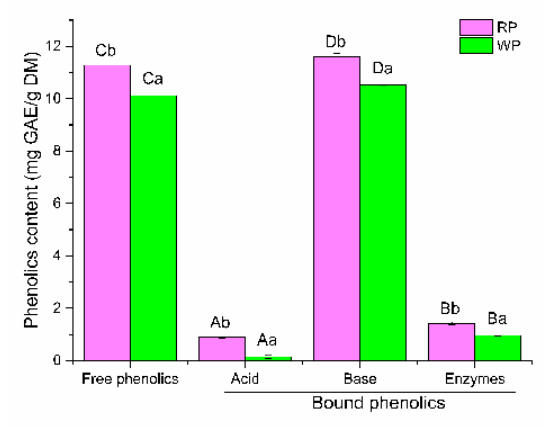

(a)

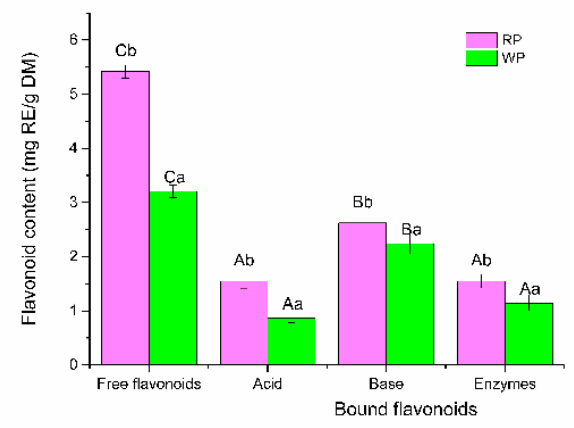

(b)

Figure 2. (a) The total phenolic contents released from RP or WP after different treatments; (b) The flavonoid contents released from RP or WP after different treatments. A-D: statistically significant differences among different extraction methods for RP or WP; $a, b$ : statistically significant differences between RP and WP samples at different extraction methods. RP, red-pulp pitahaya peel; WP, white-pulp pitahaya peel. GAE, Gallic acid equivalents. RE, Rutin equivalents.

The results suggested that base hydrolysis method was more effective than acid and composite enzymes treatment for releasing the bound phenolics in RP and WP, which was consistent with our previous report [21]. They found that alkaline hydrolysis more efficiently liberated bound phenolic compounds in apple pomace than acid hydrolysis. Kim et al. [28] also reported that alkaline hydrolysis released more phenolics from wheat bran than acid hydrolysis. However, the results were different from another previous report [13], in which acidic hydrolysis exhibited more effective ability than base hydrolysis for liberating the bound phenolic compounds in Rubus idaeus L. leaves and seeds. It may ascribe to the difference in bond types by which bound phenolics linking to plants matrices in different food as well as the different food matrices. Base hydrolysis is efficient to break the ether and ester bonds linking phenolic compounds to the cell wall, which widely distributed in fruit peel [8]. However, acid hydrolysis mainly breaks glycosidic bonds. Moreover, Verma et al. [29] reported that acid hydrolysis at elevated temperature resulted in the loss of some phenolics. This may result in more efficiency of base hydrolysis than acidic hydrolysis to release bound phenolics from RP and WP.

\subsection{Identification of Phenolic Compositions in RP and WP}

Individual phenolic components liberated from RP and WP were identified and quantified by UPLC-TOF-MS method. The identified compositions of phenolics are shown in Table 2. Up to 37 individual phenolic compounds were detected and tentatively categorized based on their retention time, accurate mass parent ion peaks and secondary fragment 
ions including 5 hydroxybenzoic acids and derivatives, 11 hydroxycinnamic acids and derivatives, 19 flavonoids and two other substances. In total, 14 phenolic compounds were confirmed and validated with the standards including quercetin, kaempferol, gallic acid, chlorogenic acid, cryptochlorogenic acid, caffeic acid, syringic acid, epicatechin, $p$-coumaric acid, rutin, isoquercitrin, ferulic acid, nicotiflorin, and astragalin.

Table 2. Identification of the main phenolic compositions released from RP and WP following different extractions.

\begin{tabular}{|c|c|c|c|c|c|c|}
\hline No. & RT (min) & Compounds & Formula & $m / z[\mathbf{M}-\mathbf{H}]$ & $m / z$ Fragments & Phenolics Fractions \\
\hline & & Hydroxybenzoic acids and derivatives & & & & \\
\hline 1 & 4.73 & gallic acid ${ }^{a, b}$ & $\mathrm{C}_{7} \mathrm{H}_{6} \mathrm{O}_{5}$ & 169.00 & $125.05,78.95$ & $\mathrm{~F} 1, \mathrm{~F} 2, \mathrm{~A} 1, \mathrm{~A} 2, \mathrm{~B} 1, \mathrm{~B} 2, \mathrm{E} 1$ \\
\hline 2 & 5.29 & 4-methoxysalicylic acid ${ }^{a, b}$ & $\mathrm{C}_{8} \mathrm{H}_{8} \mathrm{O}_{4}$ & 167.03 & 123.04 & E2 \\
\hline 4 & 7.31 & syringic acid ${ }^{a, b}$ & $\mathrm{C}_{9} \mathrm{H}_{10} \mathrm{O}_{5}$ & 197.04 & 153.05 & $\mathrm{~F} 1, \mathrm{~F} 2, \mathrm{~A} 1, \mathrm{~A} 2$ \\
\hline 12 & 8.67 & methyl vanillate $^{b}$ & $\mathrm{C}_{9} \mathrm{H}_{10} \mathrm{O}_{4}$ & 181.05 & 166.03 & $\mathrm{~F} 2$ \\
\hline 21 & 10.97 & sinapic acid ${ }^{a, b}$ & $\mathrm{C}_{11} \mathrm{H}_{12} \mathrm{O}_{5}$ & 223.06 & $193.01,149.02$ & B1 \\
\hline & & Hydroxycinnamic acids and derivatives & & & & \\
\hline 3 & 7.30 & chlorogenic acid a,b & $\mathrm{C}_{16} \mathrm{H}_{18} \mathrm{O}_{9}$ & 353.09 & $161.02,191.06$ & $\mathrm{~F} 1, \mathrm{~F} 2, \mathrm{~A} 1, \mathrm{~A} 2, \mathrm{~B} 1, \mathrm{~B} 2, \mathrm{E} 1, \mathrm{E} 2$ \\
\hline 6 & 7.33 & cryptochlorogenic acid $^{\mathrm{a}, \mathrm{b}}$ & $\mathrm{C}_{16} \mathrm{H}_{18} \mathrm{O}_{9}$ & 353.09 & $173.05,191.06$ & $\mathrm{~A} 1, \mathrm{~A} 2, \mathrm{~B} 1, \mathrm{~B} 2, \mathrm{E} 2$ \\
\hline 7 & 7.35 & $p$-hydroxycinnamic acid ${ }^{\mathrm{a}, \mathrm{b}}$ & $\mathrm{C}_{9} \mathrm{H}_{8} \mathrm{O}_{3}$ & 163.04 & 119.05 & $\mathrm{~F} 1$ \\
\hline 9 & 8.15 & esculetin ${ }^{b}$ & $\mathrm{C}_{9} \mathrm{H}_{6} \mathrm{O}_{4}$ & 177.02 & 149.02 & B1 \\
\hline 11 & 8.34 & caffeic acid $^{a, b}$ & $\mathrm{C}_{9} \mathrm{H}_{8} \mathrm{O}_{4}$ & 179.03 & $135.04,107.05$ & $\mathrm{~F} 1, \mathrm{~F} 2, \mathrm{~A} 1, \mathrm{~A} 2, \mathrm{~B} 1, \mathrm{~B} 2, \mathrm{E} 1, \mathrm{E} 2$ \\
\hline 13 & 8.88 & 7,8-dihydroxycoumarin ${ }^{b}$ & $\mathrm{C}_{9} \mathrm{H}_{6} \mathrm{O}_{4}$ & 177.02 & 149.02 & $\mathrm{~F} 1, \mathrm{~B} 1$ \\
\hline 18 & 10.28 & $\rho$-coumaric acid ${ }^{a, b}$ & $\mathrm{C}_{9} \mathrm{H}_{8} \mathrm{O}_{3}$ & 163.04 & 119.05 & $\mathrm{~F} 1, \mathrm{~F} 2, \mathrm{~A} 1, \mathrm{~A} 2, \mathrm{~B} 1, \mathrm{~B} 2, \mathrm{E} 1, \mathrm{E} 2$ \\
\hline 22 & 11.06 & ferulic acid ${ }^{a, b}$ & $\mathrm{C}_{10} \mathrm{H}_{10} \mathrm{O}_{4}$ & 192.05 & $134.04,178.03$ & $\mathrm{~F} 1, \mathrm{~F} 2, \mathrm{~A} 1, \mathrm{~A} 2, \mathrm{~B} 1, \mathrm{~B} 2, \mathrm{E} 1, \mathrm{E} 2$ \\
\hline 27 & 12.65 & 1,3-dicaffeoylquinic acid ${ }^{a, b}$ & $\mathrm{C}_{25} \mathrm{H}_{24} \mathrm{O}_{12}$ & 515.12 & $353.09,191.06$ & $\mathrm{~F} 2$ \\
\hline 28 & 13.74 & isoferulic acid ${ }^{a, b}$ & $\mathrm{C}_{10} \mathrm{H}_{10} \mathrm{O}_{4}$ & 193.05 & $134.04,178.03$ & $\mathrm{~B} 1, \mathrm{~B} 2, \mathrm{E} 1, \mathrm{E} 2$ \\
\hline 32 & 16.48 & $\begin{array}{c}\text { methyl 4-hydroxycinnamate }{ }^{b} \\
\text { Flavonoids }\end{array}$ & $\mathrm{C}_{10} \mathrm{H}_{10} \mathrm{O}_{3}$ & 177.06 & 145.03 & $\mathrm{~F} 1, \mathrm{~F} 2, \mathrm{~A} 2, \mathrm{E} 1, \mathrm{E} 2$ \\
\hline 8 & 7.96 & gentiopicrin $^{\mathrm{a}, \mathrm{b}}$ & $\mathrm{C}_{16} \mathrm{H}_{20} \mathrm{O}_{9}$ & 355.10 & 149.06 & F1 \\
\hline 10 & 8.15 & $\operatorname{androsin}^{b}$ & $\mathrm{C}_{15} \mathrm{H}_{20} \mathrm{O}_{8}$ & 327.11 & 165.05 & $\mathrm{~F} 2$ \\
\hline 14 & 9.37 & Epicatechin ${ }^{a, b}$ & $\mathrm{C}_{15} \mathrm{H}_{14} \mathrm{O}_{6}$ & 289.10 & $244.90,108.90$ & $\mathrm{~F} 1, \mathrm{~F} 2$ \\
\hline 15 & 9.73 & grosvenorine $^{\mathrm{a}, \mathrm{b}}$ & $\mathrm{C}_{33} \mathrm{H}_{40} \mathrm{O}_{19}$ & 739.21 & 285.04 & $\mathrm{~F} 1$ \\
\hline 16 & 9.78 & rutin $^{a, b}$ & $\mathrm{C}_{27} \mathrm{H}_{30} \mathrm{O}_{16}$ & 609.15 & 300.03 & $\mathrm{~F} 1, \mathrm{~F} 2, \mathrm{~A} 1, \mathrm{~A} 2, \mathrm{~B} 1, \mathrm{~B} 2, \mathrm{E} 1, \mathrm{E} 2$ \\
\hline 17 & 9.83 & typhaneoside $^{\mathrm{b}}$ & $\mathrm{C}_{34} \mathrm{H}_{42} \mathrm{O}_{20}$ & 769.22 & $314.04,151.00$ & $\mathrm{~F} 1, \mathrm{~F} 2, \mathrm{~B} 1, \mathrm{~B} 2, \mathrm{E} 2$ \\
\hline 19 & 10.64 & lonicerin ${ }^{b}$ & $\mathrm{C}_{27} \mathrm{H}_{30} \mathrm{O}_{15}$ & 593.15 & $447.09,285.04$ & $\mathrm{~F} 1, \mathrm{~F} 2$ \\
\hline 20 & 10.95 & isoquercetin $^{\mathrm{a}, \mathrm{b}}$ & $\mathrm{C}_{21} \mathrm{H}_{20} \mathrm{O}_{12}$ & 463.09 & $300.03,271.03$ & $\mathrm{~F} 1, \mathrm{~F} 2, \mathrm{~A} 1, \mathrm{~A} 2, \mathrm{~B} 1, \mathrm{~B} 2, \mathrm{E} 1, \mathrm{E} 2$ \\
\hline 23 & 11.49 & nicotiflorin $^{\mathrm{a}, \mathrm{b}}$ & $\mathrm{C}_{27} \mathrm{H}_{30} \mathrm{O}_{15}$ & 593.15 & 285.04 & $\mathrm{~F} 1, \mathrm{~F} 2, \mathrm{~A} 1, \mathrm{~A} 2, \mathrm{~B} 1, \mathrm{~B} 2, \mathrm{E} 1, \mathrm{E} 2$ \\
\hline 24 & 11.50 & kaempferol 3-glucorhamnoside ${ }^{b}$ & $\mathrm{C}_{27} \mathrm{H}_{30} \mathrm{O}_{15}$ & 593.15 & $284.03,327.05$ & E2 \\
\hline 25 & 11.72 & isorhamnetin-3-O-neohesperidine $^{b}$ & $\mathrm{C}_{28} \mathrm{H}_{32} \mathrm{O}_{16}$ & 623.16 & $314.04,271.02$ & $\mathrm{~F} 1, \mathrm{~F} 2, \mathrm{~B} 1, \mathrm{~B} 2, \mathrm{E} 1, \mathrm{E} 2$ \\
\hline 26 & 12.12 & astragalin ${ }^{\mathrm{a}, \mathrm{b}}$ & $\mathrm{C}_{21} \mathrm{H}_{20} \mathrm{O}_{11}$ & 447.09 & $284.03,227.03$ & $\mathrm{~F} 1, \mathrm{~F} 2, \mathrm{~B} 2, \mathrm{E} 1, \mathrm{E} 2$ \\
\hline 29 & 13.97 & Diosmin ${ }^{a, b}$ & $\mathrm{C}_{28} \mathrm{H}_{32} \mathrm{O}_{15}$ & 607.17 & 299.06 & $\mathrm{~F} 2$ \\
\hline 31 & 15.95 & quercetin $^{\mathrm{a}, \mathrm{b}}$ & $\mathrm{C}_{15} \mathrm{H}_{10} \mathrm{O}_{7}$ & 301.04 & 151,179 & $\mathrm{~F} 1, \mathrm{~F} 2, \mathrm{~A} 1, \mathrm{~A} 2, \mathrm{~B} 1, \mathrm{E} 1, \mathrm{E} 2$ \\
\hline 33 & 16.58 & calycosin $^{b}$ & $\mathrm{C}_{16} \mathrm{H}_{12} \mathrm{O}_{5}$ & 283.06 & 268.04 & $\mathrm{~F} 1$ \\
\hline 34 & 17.55 & kaempferol ${ }^{a, b}$ & $\mathrm{C}_{15} \mathrm{H}_{10} \mathrm{O}_{6}$ & 285.04 & 151.00 & $\mathrm{~F} 1, \mathrm{~F} 2, \mathrm{~A} 1, \mathrm{~A} 2, \mathrm{~B} 1, \mathrm{~B} 2, \mathrm{E} 1, \mathrm{E} 2$ \\
\hline 35 & 17.76 & isorhamnetinab & $\mathrm{C}_{16} \mathrm{H}_{12} \mathrm{O}_{7}$ & 315.05 & $300.03,151.00$ & $\mathrm{~F} 2, \mathrm{~A} 1, \mathrm{~A} 2, \mathrm{E} 1, \mathrm{E} 2$ \\
\hline 36 & 17.93 & baicalein ${ }^{a, b}$ & $\mathrm{C}_{15} \mathrm{H}_{10} \mathrm{O}_{5}$ & 269.05 & 251.03 & $\mathrm{~F} 2$ \\
\hline 37 & 18.12 & $\begin{array}{l}\text { tectorigenin }^{b} \\
\text { Others }\end{array}$ & $\mathrm{C}_{16} \mathrm{H}_{12} \mathrm{O}_{6}$ & 299.06 & 284.03 & $\mathrm{~F} 2, \mathrm{~A} 1$ \\
\hline 5 & 7.32 & quinic acid ${ }^{b}$ & $\mathrm{C}_{7} \mathrm{H}_{12} \mathrm{O}_{6}$ & 191.06 & 127.04 & $\mathrm{~F} 2$ \\
\hline 30 & 15.12 & 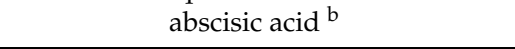 & $\mathrm{C}_{15} \mathrm{H}_{20} \mathrm{O}_{4}$ & 263.13 & $163.08,219.14$ & B1 \\
\hline
\end{tabular}

${ }^{a}$ compared with reference standards, ${ }^{b}$ compared with references. F1: Free phenolics of RP by methanol extraction; F2: Free phenolics of WP by methanol extraction; A1: Bound phenolics of RP by acid hydrolysis; A2: Bound phenolics of WP by acid hydrolysis; B1: Bound phenolics of RP by base hydrolysis; B2: Bound phenolics of WP by base hydrolysis; E1: Bound phenolics of RP by composite enzymes hydrolysis; E2: Bound phenolics of WP by composite enzymes hydrolysis.

According to the peak with parent ion, $m / z 169.00(\mathrm{M}-\mathrm{H})$ corresponded to fragment ions at $m / z 125.05$ and 78.95; compound 1 was positively identified as gallic acid. Compound 2 was very likely to be 4 -methoxysalicylic acid with parent ion $167.03(\mathrm{M}-\mathrm{H})$, and thus creating fragment ions at $m / z 123.04\left[(\mathrm{M}-\mathrm{H})-\mathrm{CO}_{2}\right]^{-}$, due to loss of a $\mathrm{CO}_{2}$. Compound 3 and compound 6 were characterized by the parent ion $m / z 353.09(\mathrm{M}-\mathrm{H})$ and their secondary fragment ions $m / z$ at 173.05 and 135.04. Compared with the retention time of standards, compound $\mathbf{3}$ and compound $\mathbf{6}$ were positively identified as chlorogenic acid and cryptochlorogenic acid, respectively. The parent ion of compound 4 was $m / z 197.04$ and fragments iron at $m / z$ 153.05, and was tentatively confirmed as syringic acid [30]. 
Compound 5 was tentatively identified as quinic acid with parent ion $m / z 191.06(\mathrm{M}-\mathrm{H})$, and thus creating fragment ions at $m / z 127.04\left[(\mathrm{M}-\mathrm{H})-2 \mathrm{CH}_{2} \mathrm{OH}\right]^{-}$. Compound 7 was very likely to be $p$-hydroxycinnamic acid with parent ion $m / z 163.04(\mathrm{M}-\mathrm{H})$, and thus creating fragment ions at $m / z 119.05\left[(\mathrm{M}-\mathrm{H})-\mathrm{CO}_{2}\right]^{-}$, due to loss of a $\mathrm{CO}_{2}$. Compound 8 was tentatively identified as gentipicrin with parent ion $m / z 355.10(\mathrm{M}-\mathrm{H})$, and its creating ions fragments $m / z$ at $149.06\left[(\mathrm{M}-\mathrm{H})-\mathrm{glc}-\mathrm{CO}_{2}\right]^{-}$, due to the loss of a hexosyl residue and $\mathrm{CO}_{2}$. Compound 9 was identified as esculetin with parent ion $\mathrm{m} / z 177.02$ $(\mathrm{M}-\mathrm{H})$, and thus creating fragment ions at $m / z 149.02[(\mathrm{M}-\mathrm{H})-\mathrm{CO}]^{-}$. As the loss of a hexosyl residue, compound $10\left([\mathrm{M}-\mathrm{H}]^{-}\right.$at $m / z$ 327.11) created fragment ions at $m / z$ 165.05 and be identified as androsin. By comparing the retention time of standard compounds, compound 11, 14, 16, 18, 20, 22, 26, 28, 31 and 35 were identified as caffeic acid, epicatechin, rutin, $p$-coumaric acid, isoquercetin, ferulic acid, astragalin, isoferulic acid, quercetin and kaempferol, respectively. Compound $\mathbf{1 2}$ was identified as methyl vanillate with parent ion $m / z 181.05(\mathrm{M}-\mathrm{H})$, and its creating ions fragments $m / z$ at 166.03 $\left[(\mathrm{M}+\mathrm{H})-\mathrm{H}_{2} \mathrm{O}\right]^{+}$. Compound 13 was identified as 7,8-dihydroxycoumarin with parent ion $m / z 177.02(\mathrm{M}-\mathrm{H})$, and thus creating fragment ions at $m / z 149.02[(\mathrm{M}-\mathrm{H})-\mathrm{CO}]^{+}$. Compound 15 was very likey to be grosvenorine with parent ion $m / z 739.21(\mathrm{M}-\mathrm{H})$, and one fragment ion at $m / z$ 285.04. Compound 17 was very likely to be typhaneoside by its parent ion $m / z 769.22$ and two fragment ions at $m / z 314.04$ and 151.00. Compound 19 was identified as lonicerin with parent ion $m / z 593.15(\mathrm{M}-\mathrm{H})$, and thus creating fragment ions at $m / z 447.09\left[(\mathrm{M}-\mathrm{H})-2 \mathrm{C}_{3} \mathrm{H}_{7} \mathrm{OCH}_{2}\right]^{-}$and $m / z 285.04\left[(\mathrm{M}-\mathrm{H})-2 \mathrm{C}_{3} \mathrm{H}_{7} \mathrm{OCH}_{2}-\mathrm{glc}^{-}\right.$ Compound 21 was tentatively identified as sinapic acid according to the ion of $m / z 223.06$ and its secondary fragment ions $m / z$ at 193.01 and 149.02 [31]. Compound 23 and 24 gave $m / z 593.15$, which corresponded to formula $\mathrm{C}_{27} \mathrm{H}_{30} \mathrm{O}_{15}$ and had kaempferol characteristic fragment ions, were identified as kaempferol-3-o-rutinoside (nicotiflorin) and kaempferol3-glucorhamnoside, respectively, based on the similar fragmentation pattern reported by Zulkifli, Abd Gani, Zaidan and Halmi [31] and Correa-Betanzo et al. [32]. Compound 25 was tentatively identified as isorhamnetin-3-o-neohesperidine according to the ion of $m / z 623.16$ and secondary fragment ions $m / z$ at 314.04 and 271.02. Compound 32 was identified as methyl 4-hydroxycinnamate with parent ion $m / z 177.06(\mathrm{M}-\mathrm{H})$, and thus creating fragment ions at $m / z 145.03\left[(\mathrm{M}-\mathrm{H})-\mathrm{CH}_{2} \mathrm{OH}\right]^{-}$. Compound 27 was very likely to be 1,3-dicaffeoylquinic acid with parent ion $m / z 515.12(\mathrm{M}-\mathrm{H})$, and thus creating fragment ions at $m / z 353.09\left[(\mathrm{M}-\mathrm{H})-\mathrm{glc}^{-}\right.$and $m / z 191.06[(\mathrm{M}-\mathrm{H})-2 \mathrm{glc}]^{-}$. Compound 29 was tentatively to be diosmin with parent ion $m / z 607.17(\mathrm{M}-\mathrm{H})$, and thus creating one fragment ion at $m / z 299.06\left[(\mathrm{M}-\mathrm{H})-2 \mathrm{C}_{3} \mathrm{H}_{7} \mathrm{OCH}_{2}-\mathrm{glc}\right]^{-}$. Compound 30 was identified as abscisic acid with parent ion $m / z 263.13(\mathrm{M}-\mathrm{H})$, and thus creating fragment ions at $m / z 219.14\left[(\mathrm{M}-\mathrm{H})-\mathrm{CO}_{2}\right]^{-}$and $m / z 163.08\left[(\mathrm{M}-\mathrm{H})-\mathrm{C}_{4} \mathrm{H}_{9} \mathrm{COCH}_{2}\right]^{-}$. Compound 33 was identified as calycosin with parent ion $m / z 283.06(\mathrm{M}-\mathrm{H})$, and thus creating fragment ions at $m / z 268.04\left[(\mathrm{M}+\mathrm{H})-\mathrm{H}_{2} \mathrm{O}\right]^{+}$. Compound 35 was tentatively identified as isorhamnetin according to the ion of $m / z 313.05$ and its MS/MS fragment ions at 300.03 and 151.00 [33]. Compound 36 was identified as baicalein with parent ion $m / z 269.05(\mathrm{M}-\mathrm{H})$, and its creating ions fragments $m / z$ at $251.03\left[(\mathrm{M}-\mathrm{H})-\mathrm{H}_{2} \mathrm{O}\right]^{-}$, due to the loss of a $\mathrm{H}_{2} \mathrm{O}$. As the loss of a $\mathrm{CH}_{3}$, compound $37\left([\mathrm{M}-\mathrm{H}]^{-}\right.$at $\left.m / z 299.06\right)$ created fragment ions at $m / z 284.03$ and be identified as tectorigenin.

\subsection{Quantity of Predominant Individual Phenolic Compounds in Various Extracts}

Table 3 showed contents of predominant individual phenolic compounds released from RP and WP following different hydrolysis methods. The absolute amounts of the individual phenolic compounds detected were between $0.05-131.67 \mathrm{mg} / \mathrm{kg}$ DW. Among all the free and bound phenolics, the major phenolic compounds in RP identified were chlorogenic acid (19.14-19.45 mg/kg DW), ferulic acid (10.72-25.04), p-coumaric acid (8.62-16.29) and caffeic acid (5.44-57.03), whereas chlorogenic acid (132.71-133.88), caffeic acid (12.96-33.16), rutin (11.58-11.93), isoquercetin (10.73-11.28) and ferulic acid (7.91-21.52) were the main compounds in WP. The major free phenolic compounds in the $80 \%$ methanol extract for 
RP (F1) identified were chlorogenic acid (17.75 mg/kg DW), quercetin (7.18), ferulic acid (6.68), p-coumaric acid (4.96) and nicotiflorin (4.18), whereas the major free phenolics for WP (F2) were chlorogenic acid (131.67), rutin (11.03), isoquercetin (10.30), caffeic acid (7.73), and ferulic acid (5.27). For bound phenolics released by acid, base and composite enzymes extraction, the major individual phenolics were all the same substances-caffeic acid, ferulic acid and $p$-coumaric acid. Extraction by base hydrolysis of RP (B1) and WP (B2) released most caffeic acid (54.18 for B1, 25.43 for B2), ferulic acid (18.36 for B1, 16.25 for B2) and p-coumaric acid (11.33 for B1, 6.63 for B2). While for acid and composite enzymes hydrolysis extracts, the major phenolics were ferulic acid (9.88 for A1, 5.27 for A2, 4.04 for E1, 2.64 for E2), p-coumaric acid (3.66 for A1, 3.48 for A2, 5.56 for E1, 3.09 for E2), and caffeic acid (2.59 for A1, 5.23 for A2, 3.4 for E1, 5.35 for E2). Different hydrolysis methods have a great influence on the content of individual phenolic compounds extracted from pitahaya peel. As present in Table 3, the quantitative results showed that many individual phenolics were increased after base hydrolysis, including caffeic acid (19-fold for RP, 3.29-fold for WP), p-coumaric acid (2.28-fold for RP, 1.91-fold for WP), and ferulic acid (2.75-fold for RP, 3.08-fold for WP). Compared with the other two methods, base hydrolysis extraction exhibited the biggest potential to release bound individual phenolic compounds. In addition, the difference in kinds and content of individual phenolics between two species was ascribed to the species heredity.

\subsection{Antioxidant Activity of Phenolics in RP and WP}

A previous research reported that free phenolic compounds in the pulp of two species of pitahaya fruits exhibited a high antioxidant activity [20]. However, the antioxidant activity of bound phenolics in pitahaya peel remained unknown. In the present work, the $\mathrm{ABTS}^{+}, \mathrm{DPPH}$ radical scavenging activity and ferric reducing antioxidant activity (FRAP) were accordingly measured to estimate the antioxidant activity of bound phenolics released from RP and WP following different hydrolysis. As shown in Table 4, free phenolics extracts showed high $\mathrm{ABTS}^{+}$, DPPH and FRAP values $(13.03 \mu \mathrm{mol}$ TE/g DW, $6.82 \mu \mathrm{mol} \mathrm{TE} / \mathrm{g}$ DW and 102.69 $\mu \mathrm{mol} \mathrm{Fe}(\mathrm{II}) \mathrm{SE} / \mathrm{g}$ DW for RP, $13.43 \mu \mathrm{mol} \mathrm{TE} / \mathrm{g} \mathrm{DW}, 7.01 \mu \mathrm{mol} \mathrm{TE} / \mathrm{g} \mathrm{DW}$ and $107.99 \mu \mathrm{mol} F e(\mathrm{II}) \mathrm{SE} / \mathrm{g} \mathrm{DW}$ for WP). In bound phenolics extracts of RP, it was observed that the base hydrolysis extracts retained the highest $\mathrm{ABTS}^{+}$and DPPH values $(33.62 \mu \mathrm{mol}$ TE/g DW for $\mathrm{ABTS}^{+}, 31.34 \mu \mathrm{mol} \mathrm{TE} / \mathrm{g}$ DW for DPPH and $237.25 \mu \mathrm{mol} \mathrm{Fe(II)SE/g} \mathrm{DW}$ for FRAP) $(p<0.01)$, while the extracts obtained by composite enzymes hydrolysis and the acid hydrolysis both showed low $\mathrm{ABTS}^{+}$and DPPH values. Concerning WP, the $\mathrm{ABTS}^{+}$, DPPH and FRAP values of bound phenolics from base hydrolysis were obviously higher than those from the other two hydrolysis methods $(p<0.01)$. Previous studies showed that the antioxidant activity of polyphenols-rich extracts from plant was closely related to the presence of phenolic compounds [34]. After extracted by $80 \%$ methanol, base hydrolysis released a large number of phenolic compounds. Nevertheless, acid and composite enzymes hydrolysis displayed a low efficiency in releasing the bound phenolics in RP and WP, which may result in the low antioxidant activities. Additionally, caffeic acid and ferulic acid were found to possess the stronger antioxidant activity compared with several other individual phenolic compounds [29]. The high amounts of caffeic acid and ferulic acid was released by base hydrolysis, which may contribute to the stronger antioxidant activity of extracts from base hydrolysis compared to the two other hydrolysis methods. Considering the comparatively higher antioxidant activities and lower content of bound phenolics by base hydrolysis compared with free phenolics, our results indicated that the comparatively high concentration of caffeic acid, $p$-coumaric acid and syringic acid in bound phenolics may play an important role in the antioxidant activities performance of RP and WP. Consequently, base hydrolysis method was the most efficient extraction to liberate the antioxidative phenolic components from RP and WP. 
Table 3. Content of predominant individual phenolic compounds released from RP and WP following different extractions.

\begin{tabular}{|c|c|c|c|c|c|c|}
\hline \multirow[t]{3}{*}{ Class } & \multirow[t]{3}{*}{ Sub-Class } & \multirow[t]{3}{*}{ Analytes } & \multicolumn{4}{|c|}{ Contents (mg/kg DW) } \\
\hline & & & \multicolumn{4}{|c|}{ Red-pulp pitahaya peel } \\
\hline & & & $\mathrm{F} 1$ & $\mathrm{~A} 1(\%)$ & B1 (\%) & E1 (\%) \\
\hline \multirow{11}{*}{ Phenolic acids } & \multirow{4}{*}{ Hydroxybenzoic acids } & gallic acid & $1.45 \pm 0.02$ & $1.50 \pm 0.76(50.85)$ & $1.42 \pm 0.72(49.48)$ & $0.95 \pm 0.51(39.58)$ \\
\hline & & 4-methoxysalicylic acid & $0.53 \pm 0.01$ & $0.35 \pm 0.00(39.77)$ & $0.55 \pm 0.01(50.93)$ & $0.23 \pm 0.01(30.26)$ \\
\hline & & syringic acid & $2.43 \pm 0.13$ & $1.77 \pm 0.04(42.14)$ & ND & ND \\
\hline & & sinapic acid & $1.15 \pm 0.01$ & $1.05 \pm 0.31(47.73)$ & $1.25 \pm 0.72(52.08)$ & $0.35 \pm 0.51(23.33)$ \\
\hline & & chlorogenic acid & $17.75 \pm 1.09$ & $1.54 \pm 0.06(7.98)$ & $1.70 \pm 0.95(8.74)$ & $1.39 \pm 0.05(7.26)$ \\
\hline & \multirow{6}{*}{ Hydroxycinnamic acids } & cryptochlorogenic acid & ND & $0.87 \pm 0.00(100.00)$ & $0.85 \pm 0.03(100.00)$ & ND \\
\hline & & $p$-hydroxycinnamic acid & $1.25 \pm 0.05$ & $0.85 \pm 0.01(40.48)$ & $1.45 \pm 0.07(53.70)$ & $0.37 \pm 0.02(14.12)$ \\
\hline & & caffeic acid & $2.85 \pm 0.25$ & $2.59 \pm 0.62(47.61)$ & $54.18 \pm 3.06(95.00)$ & $3.40 \pm 0.41(54.40)$ \\
\hline & & $p$-coumaric acid & $4.96 \pm 0.25$ & $3.66 \pm 0.21(42.46)$ & $11.33 \pm 0.90(69.55)$ & $5.56 \pm 0.39(52.85)$ \\
\hline & & ferulic acid & $6.68 \pm 1.27$ & $9.88 \pm 1.88(59.66)$ & $18.36 \pm 3.37(73.32)$ & $4.04 \pm 0.73(37.69)$ \\
\hline & & 1,3-dicaffeoylquinic acid & $1.58 \pm 0.13$ & $1.57 \pm 0.12(49.84)$ & $1.65 \pm 0.07(51.08)$ & $0.59 \pm 0.01(27.19)$ \\
\hline \multirow{12}{*}{ Flavonoids } & & isoferulic acid & $1.65 \pm 0.03$ & $1.00 \pm 0.11(37.74)$ & $1.55 \pm 0.37(48.44)$ & ND \\
\hline & & epicatechin & $2.00 \pm 0.89$ & ND & ND & ND \\
\hline & & kaempferol & $1.37 \pm 0.07$ & $1.32 \pm 0.12(49.07)$ & $1.10 \pm 0.21(44.53)$ & $0.97 \pm 0.01(41.45)$ \\
\hline & & gentiopicrin & $1.07 \pm 0.03$ & $1.01 \pm 0.10(48.56)$ & $0.70 \pm 0.01(39.55)$ & $0.57 \pm 0.02(34.76)$ \\
\hline & & grosvenorine & $0.17 \pm 0.00$ & $0.31 \pm 0.02(64.58)$ & $0.19 \pm 0.02(52.78)$ & $0.17 \pm 0.01(50)$ \\
\hline & & isorhamnetin & $1.09 \pm 0.05$ & ND & $0.92 \pm 0.03(45.77)$ & ND \\
\hline & & baicalein & $0.57 \pm 0.02$ & $0.32 \pm 0.03(35.96)$ & $0.51 \pm 0.03(47.22)$ & $0.37 \pm 0.02$ \\
\hline & & astragalin & $1.19 \pm 0.06$ & ND & $0.42 \pm 0.01(26.09)$ & $0.45 \pm 0.03$ \\
\hline & & nicotiflorin & $4.18 \pm 0.19$ & $0.25 \pm 0.00(5.64)$ & $1.15 \pm 0.11(21.58)$ & $0.64 \pm 0.11(13.28)$ \\
\hline & & quercetin & $7.18 \pm 0.12$ & $0.32 \pm 0.07(4.27)$ & $0.55 \pm 0.02(7.12)$ & $0.61 \pm 0.02$ \\
\hline & & rutin & $1.76 \pm 0.00$ & $0.54 \pm 0.00(23.48)$ & $1.48 \pm 0.11(45.68)$ & $0.61 \pm 0.04$ \\
\hline & & isoquercitrin & $3.04 \pm 0.14$ & $0.43 \pm 0.00(12.39)$ & $2.73 \pm 0.30(47.31)$ & $0.60 \pm 0.04(16.48)$ \\
\hline
\end{tabular}


Table 3. Cont.

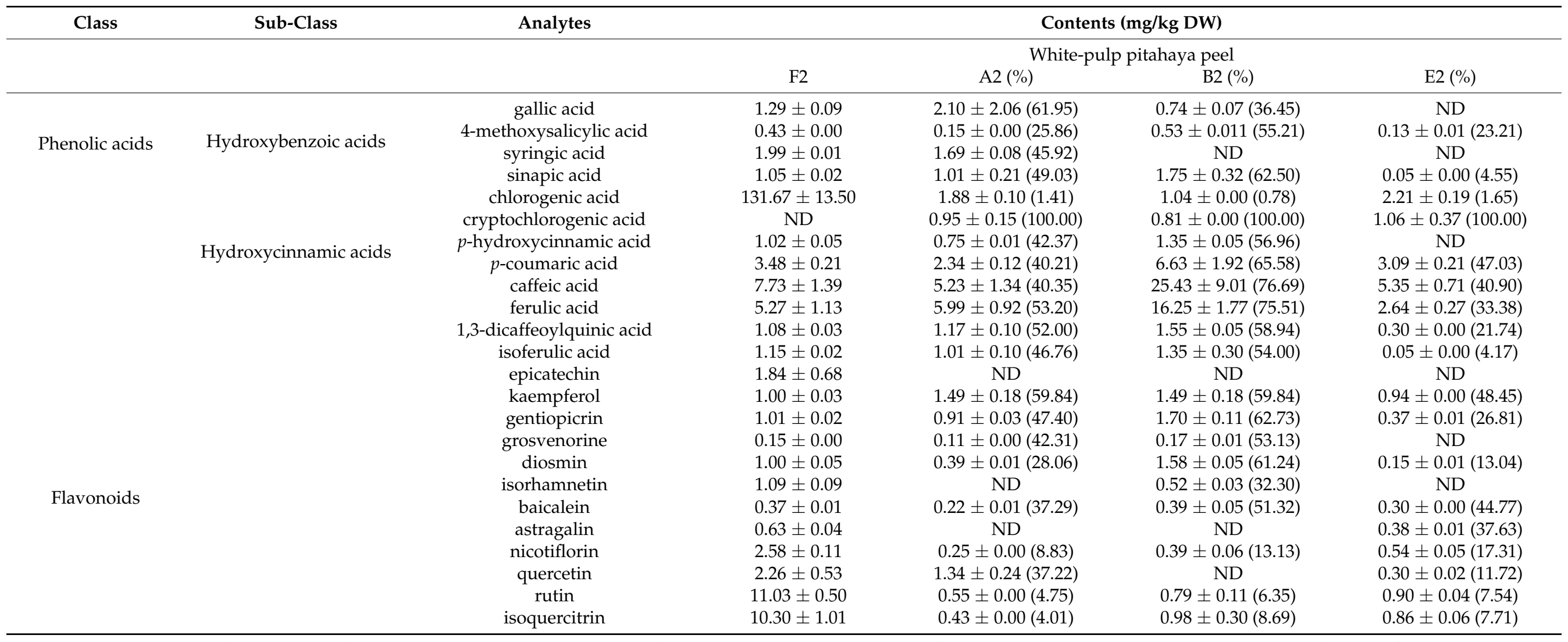

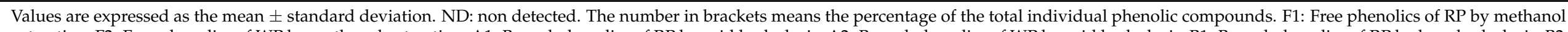

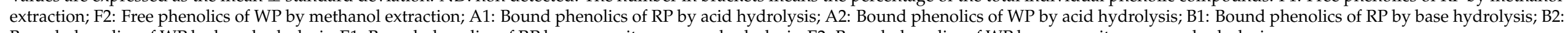
Bound phenolics of WP by base hydrolysis; E1: Bound phenolics of RP by composite enzymes hydrolysis; E2: Bound phenolics of WP by composite enzymes hydrolysis. 
Table 4. The $\mathrm{ABTS}^{+}$, DPPH radical scavenging activity and ferric reducing antioxidant activity of phenolics released from RP and WP following different extractions.

\begin{tabular}{cccc}
\hline Stage & Extraction & Red-Pulp Pitahaya Peel & White-Pulp Pitahaya Peel \\
\hline & Methanol & $13.03 \pm 0.09 \mathrm{Ba}$ & $13.43 \pm 0.03 \mathrm{Ba}$ \\
ABTS $^{+}$radical scavenging activity & Acid & $4.56 \pm 0.27 \mathrm{Aa}$ & $5.03 \pm 0.11 \mathrm{Aa}$ \\
$(\mu \mathrm{mol} \mathrm{TE} / g$ DW) & Base & $33.62 \pm 2.16 \mathrm{Ca}$ & $38.42 \pm 1.42 \mathrm{Cb}$ \\
& Composite enzymes & $4.24 \pm 0.33 \mathrm{Aa}$ & $4.15 \pm 0.18 \mathrm{Aa}$ \\
& Methanol & $6.82 \pm 0.02 \mathrm{Ba}$ & $7.01 \pm 0.20 \mathrm{Ba}$ \\
DPPH radical scavenging activity & Acid & $2.02 \pm 0.20 \mathrm{Aa}$ & $1.84 \pm 0.16 \mathrm{Aa}$ \\
$(\mu$ mol TE/g DW) & Base & $31.34 \pm 3.72 \mathrm{Cb}$ & $25.19 \pm 2.01 \mathrm{Ca}$ \\
& Composite enzymes & $1.28 \pm 0.14 \mathrm{Aa}$ & $1.08 \pm 0.15 \mathrm{Aa}$ \\
Ferric reducing/antioxidant power & Methanol & $102.69 \pm 3.27 \mathrm{Ca}$ & $107.99 \pm 1.72 \mathrm{Ca}$ \\
$(\mu$ mol Fe(II)SE /g DW) & Acid & $4.23 \pm 0.39 \mathrm{Aa}$ & $5.62 \pm 0.63 \mathrm{Aa}$ \\
& Base & $237.25 \pm 3.57 \mathrm{Da}$ & $254.2 \pm 5.07 \mathrm{Db}$ \\
\hline
\end{tabular}

Values are expressed as the mean \pm SD. Different uppercase letters (A-D) in the same column mean statistically significant differences among different treatment methods for RP or WP $(p<0.05)$. Different lowercase letters $(a, b)$ in the same row mean statistically significant differences between RP and WP samples from different treatment methods $(p<0.05)$.

\subsection{Correlation between Phenolic Compounds and Antioxidant Activity}

Pearson's correlation coefficient among DPPH, $\mathrm{ABTS}^{+}$, FRAP, TPC, TFC and predominant individual phenolic of pitahaya peel was presented in Table 5 . There were significant $(p<0.01)$ positive correlations between the TPC and the antioxidant activities $(r=0.717$, $0.803,0.872$ in $\mathrm{RP}, \mathrm{r}=0.764,0.784,0.871$ in $\mathrm{WP}$ for DPPH, $\mathrm{ABTS}^{+}$and FRAP, respectively), implying that the antioxidant capacity of pitahaya fruit peel mainly originated from its phenolic substances. The positive relationship between total phenolics content and antioxidant activity was also reported previously [35]. A direct correlation was found between the phenolic contents and antioxidant effects in the free phenolics (by methanol extraction) of pulp and peel of white and red pitahayas, collected from Jeju Island, Korea [17]. However, no significant correlation emerged between TFC and the antioxidant activities in RP and WP. This was probably due to the comparatively low flavonoid contents compared with its phenolic acid contents in RP and WP. Considering the comparatively high phenolic acids content in bound form, our results implied that phenolic acids liberated from RP and WP played important roles in the antioxidant activity performance.

Phenolic compounds in plant were already reported to be effective scavengers of free radicals. However, there is no information about the contribution of individual phenolics to their overall antioxidant capacity in pitahaya peel. To further investigate the contribution of predominant individual phenolic compound to the antioxidant capacity of phenolic extracts of RP and WP, the correlation analysis was established (Table 5). The main phenolics contributors to antioxidant capacities in WP seem to be caffeic acid $>p$ coumaric acid > syringic acid. For RP, it seems to be interesting that the main phenolics contributors to antioxidant capacities were in the following order: syringic acid $>$ caffeic acid $>p$-coumaric acid $>$ ferulic acid $>$ rutin $>$ isoquercitrin. It can also be noticed that chlorogenic acid, nicotiflorin and quercetin appeared to not contribute to the antioxidant activity for the ABTS, DPPH, and FRAP assays both in RP and WP. Unlike the RP, ferulic acid, rutin and isoquercitrin were not significant contributors for the ABTS, DPPH, and FRAP assays $(p>0.05)$ in WP. Arruda et al. [36] reported that chlorogenic acid showed few contributions to the antioxidant activity in the pulp and peel of araticum fruit. The comparatively high content of chlorogenic acid in free phenolics may result in its low value of antioxidant activities. Previous studies have shown that individual phenolic compounds present in the extracts may exert their antioxidant activity individually as well as synergistically or antagonistically [37]. This may cause individual phenolic compounds exhibited different contributes to the antioxidant activities in RP and WP. 
Table 5. Pearson's correlation coefficient analysis between the antioxidant activity and phenolics of $\mathrm{RP}$ and WP from different treatment methods.

\begin{tabular}{cccc}
\hline & DPPH & ABTS & FRAP \\
\hline TPC (RP) & $0.717^{* *}$ & $0.803^{* *}$ & $0.872^{* *}$ \\
TPC (WP) & $0.764^{* *}$ & $0.784^{* *}$ & $0.871^{* *}$ \\
TFC (RP) & 0.110 & 0.237 & 0.353 \\
TFC (WP) & $0.367^{* *}$ & 0.435 & 0.566 \\
Caffeic acid (RP) & $0.979^{* *}$ & $0.947^{* *}$ & $0.908^{* *}$ \\
Caffeic acid (WP) & $0.904^{* *}$ & $0.883^{* *}$ & $0.863^{* *}$ \\
Ferulic acid (RP) & $0.836^{* *}$ & $0.857^{* *}$ & $0.785^{* *}$ \\
Ferulic acid (WP) & $0.497^{*}$ & 0.548 & 0.51 \\
Chlorogenic acid (RP) & -0.154 & -0.023 & 0.094 \\
Chlorogenic acid (WP) & -0.111 & -0.083 & 0.067 \\
Syringic acid (RP) & $0.968^{* *}$ & $0.966^{* *}$ & $0.960^{* *}$ \\
Syringic acid (WP) & $0.968^{*}$ & $0.964^{*}$ & $0.971^{*}$ \\
Nicotiflorin (RP) & -0.029 & 0.090 & 0.214 \\
Nicotiflorin (WP) & -0.176 & -0.151 & 0.002 \\
Rutin (RP) & $0.758^{*}$ & $0.791^{*}$ & $0.851^{*}$ \\
Rutin (WP) & $-0.117^{* *}$ & -0.143 & 0.033 \\
$p$-coumaric acid (RP) & $0.947^{* *}$ & $0.929^{* * *}$ & $0.904^{* *}$ \\
$p$-coumaric acid (WP) & $0.874^{* *}$ & $0.862^{* *}$ & $0.859^{* *}$ \\
Quercetin (RP) & -0.154 & -0.028 & 0.095 \\
Quercetin (WP) & $0.016^{*}$ & 0.065 & 0.203 \\
Isoquercitrin (RP) & $0.635^{*}$ & $0.716^{* *}$ & $0.804^{* *}$ \\
Isoquercitrin (WP) & -0.073 & -0.045 & 0.107 \\
\hline
\end{tabular}

TPC, Total phenolic contents; TFC, Total flavonoid contents; ${ }^{*}$ Correlation was significant at the 0.05 level (two-tailed). ${ }^{* *}$ Correlation was significant at the 0.01 level (two-tailed).

\section{Conclusions}

This is the first report to systematically investigate the compositions and contents of bound phenolics of red-pulp and white-pulp pitahaya peel treated by different hydrolysis methods (acid, base and composite enzymes). The results indicated that base hydrolysis was the highest efficient method for releasing the bound phenolics in RP and WP. Chlorogenic acid, quercetin and ferulic acid were the major free phenolic compounds, whereas caffeic acid, ferulic acid and $p$-coumaric acid were the predominant bound phenolics in RP and WP. In addition, the antioxidant capacity of RP and WP showed a positive correlation with the total phenolics, and with specific individual phenolic compounds such as caffeic acid, ferulic acid, syringic acid and $p$-coumaric acid. These findings showed that hydrolysis methods had substantial effects on the release of bound phenolics in pitahaya peel which can be a promising source of natural antioxidants by effective extraction.

Author Contributions: Conceptualization, W.L. and R.Y.; methodology, X.L.; validation, L.W.; formal analysis, W.T., Y.Y. and L.W.; investigation, W.T. and Y.Y.; resources, C.L.; writing-original draft preparation, W.T. and W.L.; writing-review and editing, X.L. and R.Y.; funding acquisition, W.L., X.L. and R.Y. All authors have read and agreed to the published version of the manuscript.

Funding: This research was funded by the Natural Science Foundation of Hainan Province, China (grant number: 320RC511), the National Natural Science Foundation of China (grant number: 31871800), the Innovative Research Team Project for Modern Agricultural Industry Common Key Technologies of Guangdong Province (grant number: 2020KJ117) and Scientific Research Foundation of Hainan University (grant number KYQD1660).

Data Availability Statement: Not applicable.

Conflicts of Interest: The authors declare no conflict of interest. 


\section{References}

1. Ortiz-Hernandez, D.Y.; Carrillo-Salazar, A.J. Pitahaya (Hylocereus spp.): A short review. Comun. Sci. 2012, 3, $220-237$.

2. Le Bellec, F.; Vaillant, F.; Imbert, E. Pitahaya (Hylocereus spp.): A new fruit crop, a market with a future. Fruits 2006, 61, 237-250. [CrossRef]

3. Ferreres, F.; Grosso, C.; Gil-Izquierdo, A.; Valentao, P.; Mota, A.T.; Andrade, P.B. Optimization of the recovery of high-value compounds from pitaya fruit by-products using microwave-assisted extraction. Food Chem. 2017, 230, 463-474. [CrossRef] [PubMed]

4. Perez-Jimenez, J.; Saura-Calixto, F. Fruit peels as sources of non-extractable polyphenols or macromolecular antioxidants: Analysis and nutritional implications. Food Res. Int. 2018, 111, 148-152. [CrossRef]

5. Vu, H.T.; Scarlett, C.J.; Vuong, Q.V. Phenolic compounds within banana peel and their potential uses: A review. J. Funct. Foods 2018, 40, 238-248. [CrossRef]

6. Gomez-Mejia, E.; Rosales-Conrado, N.; Leon-Gonzalez, M.E.; Madrid, Y. Citrus peels waste as a source of value-added compounds: Extraction and quantification of bioactive polyphenols. Food Chem. 2019, 295, 289-299. [CrossRef]

7. Olszewska, M.A.; Gedas, A.; Simoes, M. Antimicrobial polyphenol-rich extracts: Applications and limitations in the food industry. Food Res. Int. 2020, 134, 109214. [CrossRef] [PubMed]

8. Acosta-Estrada, B.A.; Gutierrez-Uribe, J.A.; Serna-Saldivar, S.O. Bound phenolics in foods, a review. Food Chem. 2014, 152, 46-55. [CrossRef] [PubMed]

9. Puri, M.; Sharma, D.; Barrow, C.J. Enzyme-assisted extraction of bioactives from plants. Trends Biotechnol. 2012, 30, 37-44. [CrossRef]

10. Tang, Y.; Zhang, B.; Li, X.; Chen, P.X.; Zhang, H.; Liu, R.; Tsao, R. Bound phenolics of quinoa seeds released by acid, alkaline, and enzymatic treatments and their antioxidant and alpha-glucosidase and pancreatic lipase inhibitory effects. J. Agric. Food Chem. 2016, 64, 1712-1719. [CrossRef]

11. Rita, R.K.B.; Dhankar, J.; Nalla, D.B. Assessment of strawberry polyphenols aqueous extract for major compositional and biofunctional attributes. Int. J. Curr. Res. Rev. 2018, 10, 1-6. [CrossRef]

12. Zhu, H.; Zhang, J.; Li, C.; Liu, S.; Wang, L. Morinda citrifolia L. leaves extracts obtained by traditional and eco-friendly extraction solvents: Relation between phenolic compositions and biological properties by multivariate analysis. Ind. Crop. Prod. 2020, 153, 112586. [CrossRef]

13. Wang, L.; Lin, X.; Zhang, J.; Zhang, W.; Hu, X.; Li, W.; Li, C.; Liu, S. Extraction methods for the releasing of bound phenolics from Rubus idaeus L. leaves and seeds. Ind. Crop. Prod. 2019, 135, 1-9. [CrossRef]

14. Reitzer, F.; Allais, M.; Ball, V.; Meyer, F. Polyphenols at interfaces. Adv. Colloid Interface Sci. 2018, 257, 31-41. [CrossRef] [PubMed]

15. Wang, Y.K.; Zhang, X.; Chen, G.L.; Yu, J.; Yang, L.Q.; Gao, Y.Q. Antioxidant property and their free, soluble conjugate and insoluble-bound phenolic contents in selected beans. J. Funct. Foods 2016, 24, 359-372. [CrossRef]

16. Wang, K.; Li, M.; Wang, Y.; Liu, Z.; Ni, Y. Effects of extraction methods on the structural characteristics and functional properties of dietary fiber extracted from kiwifruit (Actinidia deliciosa). Food Hydrocoll. 2021, 110, 106162. [CrossRef]

17. Kim, H.; Choi, H.K.; Moon, J.Y.; Kim, Y.S.; Mosaddik, A.; Cho, S.K. Comparative antioxidant and antiproliferative activities of red and white pitayas and their correlation with flavonoid and polyphenol content. J. Food Sci. 2011, 76, 38-45. [CrossRef]

18. Tenore, G.C.; Novellino, E.; Basile, A. Nutraceutical potential and antioxidant benefits of red pitaya (Hylocereus polyrhizus) extracts. J. Funct. Foods. 2012, 4, 129-136. [CrossRef]

19. Wu, L.C.; Hsu, H.W.; Chen, Y.C.; Chiu, C.C.; Lin, Y.I.; Ho, J.A.A. Antioxidant and antiproliferative activities of red pitaya. Food Chem. 2006, 95, 319-327. [CrossRef]

20. Garcia-Cruz, L.; Duenas, M.; Santos-Buelgas, C.; Valle-Guadarrama, S.; Salinas-Moreno, Y. Betalains and phenolic compounds profiling and antioxidant capacity of pitaya (Stenocereus spp.) fruit from two species (S. Pruinosus and S. stellatus). Food Chem. 2017, 234, 111-118. [CrossRef]

21. Li, W.; Yang, R.; Ying, D.; Yu, J.; Sanguansri, L.; Augustin, M.A. Analysis of polyphenols in apple pomace: A comparative study of different extraction and hydrolysis procedures. Ind. Crop. Prod. 2020, 147, 112250. [CrossRef]

22. Singh, J.P.; Kaur, A.; Singh, N.; Nim, L.; Shevkani, K.; Kaur, H.; Arora, D.S. In vitro antioxidant and antimicrobial properties of jambolan (Syzygium cumini) fruit polyphenols. LWT Food Sci. Technol. 2016, 65, 1025-1030. [CrossRef]

23. Pascoa, R.; Teixeira, A.M.; Sousa, C. Antioxidant capacity of Camellia japonica cultivars assessed by near- and mid-infrared spectroscopy. Planta 2019, 249, 1053-1062. [CrossRef] [PubMed]

24. Arnab, A.; Goyal, A.; Middha, S. Evaluation of the DPPH radical scavenging activity, total phenols and antioxidant activities in Indian wild Bambusa vulgaris "Vittata" methanolic leaf extract. J. Nat. Pharm. 2010, 1, 40-45. [CrossRef]

25. Van der Werf, R.; Marcic, C.; Khalil, A.; Sigrist, S.; Marchioni, E. ABTS radical scavenging capacity in green and roasted coffee extracts. LWT Food Sci. Technol. 2014, 58, 77-85. [CrossRef]

26. Chen, T.S.; Liou, S.Y.; Wu, H.C.; Tsai, F.J.; Tsai, C.H.; Huang, C.Y.; Chang, Y.L. New analytical method for investigating the antioxidant power of food extracts on the basis of their electron-donating ability: Comparison to the ferric reducing/antioxidant power (FRAP) assay. J. Agric. Food Chem. 2010, 58, 8477-8480. [CrossRef] [PubMed]

27. Shahidi, F.; Yeo, J.D. Insoluble-bound phenolics in food. Molecules 2016, 21, 1216. [CrossRef]

28. Kim, K.; Tsao, R.; Yang, R.; Cui, S. Phenolic acid profiles and antioxidant activities of wheat bran extracts and the effect of hydrolysis conditions. Food Chem. 2006, 95, 466-473. [CrossRef] 
29. Verma, B.; Hucl, P.; Chibbar, R.N. Phenolic acid composition and antioxidant capacity of acid and alkali hydrolysed wheat bran fractions. Food Chem. 2009, 116, 947-954. [CrossRef]

30. Montiel-Sanchez, M.; Garcia-Cayuela, T.; Gomez-Maqueo, A.; Garcia, H.S.; Cano, M.P. In vitro gastrointestinal stability, bioaccessibility and potential biological activities of betalains and phenolic compounds in cactus berry fruits (Myrtillocactus geometrizans). Food Chem. 2020, 342, 128087. [CrossRef]

31. Zulkifli, S.A.; Abd Gani, S.S.; Zaidan, U.H.; Halmi, M.I.E. Optimization of total phenolic and flavonoid contents of defatted pitaya (Hylocereus polyrhizus) seed extract and its antioxidant properties. Molecules 2020, 25, 787. [CrossRef] [PubMed]

32. Correa-Betanzo, J.; Allen-Vercoe, E.; McDonald, J.; Schroeter, K.; Corredig, M.; Paliyath, G. Stability and biological activity of wild blueberry (Vaccinium angustifolium) polyphenols during simulated in vitro gastrointestinal digestion. Food Chem. 2014, 165, 522-531. [CrossRef] [PubMed]

33. Farag, M.A.; Sallam, I.E.; Fekry, M.I.; Zaghloul, S.S.; El-Dine, R.S. Metabolite profiling of three Opuntia ficus-indica fruit cultivars using UPLC-QTOF-MS in relation to their antioxidant potential. Food Biosci. 2020, 36, 100673. [CrossRef]

34. Wang, L.; Bei, Q.; Wu, Y.; Liao, W.; Wu, Z. Characterization of soluble and insoluble-bound polyphenols from Psidium guajava L. leaves co-fermented with Monascus anka and Bacillus sp. and their bio-activities. J. Funct. Foods 2017, 32, 149-159. [CrossRef]

35. Raudone, L.; Vilkickyte, G.; Pitkauskaite, L.; Raudonis, R.; Vainoriene, R.; Motiekaityte, V. Antioxidant activities of Vaccinium vitis-idaea L. leaves within cultivars and their phenolic compounds. Molecules 2019, 24, 844. [CrossRef]

36. Arruda, H.S.; Pereira, G.A.; de Morais, D.R.; Eberlin, M.N.; Pastore, G.M. Determination of free, esterified, glycosylated and insoluble-bound phenolics composition in the edible part of araticum fruit (Annona crassiflora Mart.) and its by-products by HPLC-ESI-MS/MS. Food Chem. 2018, 245, 738-749. [CrossRef]

37. Sumczynski, D.; Kotásková, E.; Orsavová, J.; Valášek, P. Contribution of individual phenolics to antioxidant activity and in vitro digestibility of wild rices (Zizania aquatica L.). Food Chem. 2017, 218, 107-115. [CrossRef] [PubMed] 